

\section{DISCLAIMER}

This report was prepared as an account of work sponsored by an agency of the United States Government. Neither the United States Government nor any agency thereof, nor any of their employees, make any warranty, express or implied, or assumes any legal liability or responsibility for the accuracy, completeness, or usefulness of any information, apparatus, product, or process disclosed, or represents that its use would not infringe privately owned rights. Reference herein to any specific commercial product, process, or service by trade name, trademark, manufacturer, or otherwise does not necessarily constitute or imply its endorsement, recommendation, or favoring by the United States Government or any agency thereof. The views and opinions of authors expressed herein do not necessarily state or reflect those of the United States Government or any agency thereof. 


\section{DISCLAIMER}

Portions of this document may be illegible in electronic image products. Images are produced from the best available original document. 
MATCHING DOE GRANT PROGRAM FOR UNIVERSITY NUCLEAR ENGINEERING

FINAL REPORT

1 OCTOBER 1994 - 30 SEPTEMBER 1995

\author{
PRINCIPAL INVESTIGATOR \\ ALBERT B. REYNOLDS \\ PROFESSOR OF NUCLEAR ENGINEERING \\ UNIVERSITY OF VIRGINIA
}

The matching grant from DOE for university nuclear engineering at the University of Virginia was used primarily for student support and enhancement of the Nuclear Engineering Department's computer capabilities. This DOE grant, during this 1994-95 period, was matched by $\$ 50,000$ from Duke Power Company.

\title{
Computer Purchases
}

$\$ 10,278$ was spent on upgrading the Department's computer facilities. Earlier the Department had used DOE matching funds to purchase an IBM Risc workstation and four 486 personal computers. In early 1995, the DOE grant was used to purchase two Pentium computers. In additions peripheral equipment and software were purchased. The DOE/utility grant program has been vital toward our Department's keeping up with computer facilities required to operate an excellent academic and research program in nuclear engineering education.

\section{student support}

One graduate research assistant was supported by DOE grant funds. This student worked on neutron-beam an experimental-facility designs for the University of Virginia's program in boron neutron capture therapy at the University of Virginia Reactor. This student also participated in the Argonne National Laboratory program in BNCT in Idaho during the summer. A second student who also worked on BNCT was given some supplementary funding for research. This student worked at Idaho National Engineering Laboratory on BNCT during the summer.

\section{Curriculum and Department Development and Supplies}

A small sum, $\$ 1699$, was spend on curriculum and reactor development and supplies.. Funds were spent on curriculum development in the areas of nuclear waste disposal and two phase flow. A faculty member spent time at TRW learning about their waste management program for assistance in a graduate course on waste disposal. Another faculty member spent time with Duke Power on two phase flow and subcooling to develop course work and research in this area. A third staff member attended a meeting on research reactor operation and development to enhance the program of the University of Virginia Reactor to which DOE 
recently gave a new low-enriched core. A small amount was spent on gas supplies a nuclear cable-aging research project.

\section{Summary of Income and Expenditures}

\section{Income}

From the DOE grant: $\$ 29,100$

\section{Expenditures}

Personal Computers

$\$ 10,278$

Graduate student support 15,615

Department Development

1,699

Total expenditures

$\$ 27,592$ 


\section{DISTRIBUTION LIST}

$1-2$

Beverly J. Harness, AD/423

Environmental Acquisitions Branch

Procurement \& Contracts Division, USDOE

P. O. Box 2001

Oak Ridge, TN 37831-8758

(615) 576-1816

3- 4 A. B. Reynolds

5- 6 M. Rodeffer, Clark Hall

* SEAS Postaward Research Administration

7 SEAS Preaward Research Administration

*Cover letter

JO\#6852:ph 


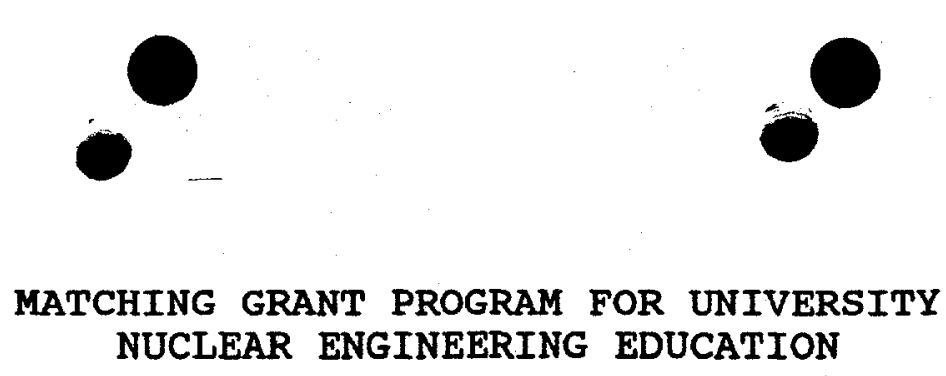

UNIVERSITY OF VIRGINIA

\author{
PROGRAM DESCRIPTION
}

It is proposed that the DOE Matching Grant Program for. University Nuclear Engineering at the University of Virginia (Grant No. DE-FG05-92ER75836) be renewed for the budget period 30 September 1995 through 29 september 1996.

The proposed grant period will coincide with the fourth year of the five-year $\$ 250,000$ Duke Power grant for support of nuclear engineering education at the University of Virginia, as described in the letter from Duke Power appended to this proposal. Duke Power is providing $\$ 50,000$ per year for five years, contingent upon continued matching support from the U.S. Department of Energy •

The DOE/utility matching program has been of great importance to the nuclear engineering program at the University of Virginia (UVA). The program is part of the Department of Mechanical, Aerospace and Nuclear Engineering. The nuclear engineering faculty is composed of six full time professors and one half time professor who is also Dean of Undergraduate Studies in the School of Engineering and Applied Science. The UVA graduate nuclear engineering program continues to be strong. There are twenty full time graduate students, nine of whom are PhD candidates. In addition there are four part time graduate students, three of whom are PhD candidates, plus about fifteen taking nuclear engineering television courses throughout virginia. The undergraduate program has been phased out, with the last class of ten students finishing this year.

The 2 MW reactor at the University of Virginia continues to operated successfully, together with an outstanding neutron radiography laboratory. The university is working with the School of Medicine in the field of boron neutron cancer therapy. A number of other research projects are underway in the nuclear engineering department, including projects in thermal hydraulics, material aging, detector development, reactor physics, and reactor operations.

Proposed Utilization of the DOE Grant for Next Year

During the 1995-96 grant period, a portion $(\$ 10,000)$ of the proposed grant from DOE will be used for further upgrade of the computer facilities at the Reactor Facility. These computers are used in the nuclear engineering program by nuclear engineering graduate students and faculty for both course work and research. 
Most of the remainder of the grant will be used for support of nuclear engineering graduate students, both for Master of Engineering candidates who do not perform research but are immediately employable by the nuclear industry, and for Masters and PhD students who do perform research.

A small amount of the grant will be spent for departmental items such as the development of nuclear engineering curricula, academic programs, computer software, and laboratory equipment.

Utilization of DOE Grant Funds During the First Three Years of the Grant

DOE has donated $\$ 129,100$ to nuclear engineering education at the University of Virginia during the first three years (19921995) of the DOE grant. Duke Power has contributed $\$ 150,000$. ie DEFG05-92ER75836 ANAL RePoRT

During these first three years, a substantial fraction of the DoE funds was used for upgrading computer needs for nuclear engineering education and research. These upgrades in computers have been of great importance to both the academic program and research programs in nuclear engineering at Virginia. A RISC 6000 series workstation was purchased for $\$ 17,000$ for nuclear engineering use at the University of Virginia Reactor Facility. With this workstation the department was able to bring on line the MCNP Monte Carlo computer code developed by Los Alamos and other computational codes not previously easily accessible for research at the Reactor Facility. \$8500 was spent on three 486 series personal computers at the Nuclear Reactor Facility plus half the cost of a laptop computer. Approximately $\$ 11000$ was spent on two Pentium computers, a 2 megabyte increase in memory for the RISC 6000 , plus software.

The remaining funds in the DOE grant wers used to support Master of Engineering graduate students and Graduate Research Assistants. This support included a stipend and in-state tuition for each student. Master of Engineering graduate students can earn an ME degree in one calendar year, though most of them take three full semesters. The Graduate Research Assistants supported by this grant have worked on a number of different research projects, including beam design for the University of Virginia Reactor to be used for boron neutron cancer therapy (BNCT), electrical cable aging studies for nuclear power plants, the development of neutron-radiography-beam-characterization standards, and dosimetry for BNCT irradiation of the breast as a treatment for breast cancer.

Utilization of the Duke Power Matching Grant

The Duke Power grant was used for the support of nuclear engineering graduate and undergraduate students, as prescribed in the Duke Power offer letter attached. 